\title{
A microeconomic perspective on the role of efficiency and equity criteria in designing natural resource policy
}

\author{
$\underline{\text { Geoff Kaine }}^{1}, \underline{\text { Suzie Greenhalgh }}^{2}, \underline{\text { Wendy Boyce }}^{3}, \underline{\text { Ruth Lourev }}^{4}, \underline{\text { Justine Young }}^{5}$, Emma Reed $^{4}, \underline{\text { Blair Keenan }}^{4}$ and Sarah Mackay $^{4}$
}

\begin{abstract}
Deliberating on policy design to manage natural resources with clarity and precision is a difficult task, even for professional and highly experienced policy practitioners. These difficulties are exacerbated by confounding the crafting of policy instruments to change resource use (a behavioral matter related to resource management) with the consequential issue of who bears the cost of changing resource use (an equity matter). The confounding of behavioral and equity issues is not surprising because equity is commonly suggested as a criterion in the literature on policy instrument choice, and inequity in access to resources may also be one of the initial drivers of policy intervention. Here, we restate the microeconomic analysis of "open access" resources and highlight the fundamental difference between efficiency (including allocative inefficiency) and equity that emerges from that analysis. We then discuss the implications of this difference for the choice of policy instruments to resolve problems in natural resource management, at least for instruments that entail changing the behavior of primary producers. This discussion is centered on three key decisions for formulating policy: (1) choosing the preferred portfolio of uses for a natural resource, (2) choosing a policy instrument to change that portfolio, and (3) choosing a mechanism to distribute the costs of change fairly. To illustrate how these decisions may play out in a real-world example, we apply the decisions to a freshwater policy process in New Zealand. By articulating the distinction, microeconomics draws distinctions between efficiency and equity as policy objectives. Linking that distinction with the Tinbergen's principle regarding the matching of instruments to objectives, we aim to reduce the conflation of the decision-making criteria employed in policy formulation decisions. In doing so, we hope to assist policy makers to avoid policy failure by reducing the potential for the influence of self-interested parties, or concern about their welfare, to introduce process failures into the policy formulation and decision-making stages of the policy cycle.
\end{abstract}

Key Words: efficiency; equity; natural resource management; policy cycle; policy design; policy instruments; public participation; water quality

\section{INTRODUCTION}

Deliberating on policy design to manage natural resources with clarity and precision is a difficult task, even for professional and highly experienced policy practitioners (Hukkinen et al. 1990, Smith and Sime 2007, Young and Kaine 2010, Godwin 2016; Murray-Darling Basin Authority, history behind the plan: http:// www.mdba.gov.au/basin-plan/developing-basin-plan/history-behindplan). These difficulties are often related to the complexity of the management problem (Muradian and Rival 2012, Cilliers et al. 2013), policy inertia related to resolving equity issues (Bromell 2012, Tadaki and Sinner 2013), and the greater awareness and involvement of stakeholders in policy decisions (Ostrom 1990, Grimble and Wellard 1997, Cox et al. 2010).

We believe many of these challenges are exacerbated by confounding the crafting of policy instruments to change resource use (a behavioral matter related to resource management) with the consequential issue of who bears the cost of changing resource use (an equity matter). The confounding of behavioral and equity issues is not surprising because equity is commonly suggested as a criterion in the literature on policy instrument choice (U.S. Congress Office of Technology Assessment 1995, Young et al. 1996, Hatton MacDonald et al. 2004, Dwyer et al. 2006, Goulder and Parry 2008, de Serres et al. 2010, Greenhalgh and Selman 2014, Mees et al. 2014). Furthermore, inequity in access to resources may also be one of the initial drivers for policy intervention.

Many authors have written on policy or decision-making processes (e.g., Heracleous 1994, Howard 2005, Sabatier 2007, Nutt 2008, Howlett 2012) and the challenges of addressing equity and efficiency within the policy process (Rose and Stevens 1993,
Pascual et al. 2010, Daigneault et al. 2017) hindering the formulation of policies to manage natural resources (Young and Kaine 2010, Phillips 2012, Sidder 2016). Here, we acknowledge the critiques and findings of these authors and offer a proposal to help policy practitioners more effectively navigate the design stage of policy formulation.

Our proposal draws on the microeconomic theory of market failure and proposes that changing how a natural resource is used is fundamentally distinct from deciding on the fair distribution of costs (and benefits) arising from changing how the resource is used, and should be treated separately. The former is a misallocation problem that requires intervening to change the behavior of resource users. The latter is an equity problem that requires intervening to redistribute the costs of change while avoiding, if possible, undermining the solution to the misallocation problem.

We contend then, that instrument choice to reallocate resource use and mechanisms to redistribute any corresponding costs are related but separate policy objectives and should be addressed using two separate instruments. This conclusion is consistent with the Tinbergen (1950) principle regarding the matching of instruments to objectives. It follows that the conflation of these objectives in the selection of policy instruments creates confusion among policy makers and stakeholders and can lead to a loss of focus on the policy objective by those formulating policy, the selection of inefficient and ineffective policy instruments, and possibly policy failure.

By articulating the distinction, microeconomics draws between efficiency and equity as policy objectives. Linking that distinction with the Tinbergen (1950) principle regarding the matching of 
instruments to objectives, we aim to reduce the conflation of the decision-making criteria employed in policy formulation decisions. In doing so, we hope to address some of the critiques of stage-based rational policy models (Heracleous 1994, Howard 2005, Howlett 2012). In particular, we hope to assist policy makers to understand better the contestable nature of the arguments advanced by competing sources of policy advice (Howard 2005) and to avoid policy failure by reducing the potential for the influence of self-interested parties or concern about their welfare (Heracleous 1994) to introduce process failures (Howlett 2012) or political failures (Heracleous 1994, Howlett 2012) into the policy formulation and decision-making stages of the policy cycle.

We first restate the microeconomic analysis of "open access" resources (Stavins 2011) and highlight the fundamental difference between efficiency (including allocative inefficiency) and equity that emerges from that analysis. We then discuss the implications of this difference for the choice of policy instruments to resolve problems in natural resource management, at least for those that entail changing the behavior of primary producers. This discussion is centered on three key decisions for formulating policy: (1) choosing the optimal portfolio of uses for a natural resource, (2) choosing a policy instrument to change that portfolio, and (3) choosing a mechanism to distribute the costs of change fairly. To illustrate how these decisions may play out in a real world example, we apply the decisions to a freshwater policy process in New Zealand (WRC 2016).

\section{THE NATURE OF POLICY PROBLEMS IN NATURAL RESOURCES}

From the perspective of microeconomics, governments create policy for two basic reasons. One is to improve the economic efficiency, i.e., the operation of the economy. The other is to improve equity, i.e., the distribution of wealth. Economic efficiency includes the allocation of resources as well as technical efficiency (Henderson and Quandt 1980). Hence, the term efficiency in this context encompasses problems such as the misallocation of natural resources. Intervening to improve efficiency is justified on the basis of increasing the wealth potentially available to all in the community; we may all be better off by making the economic cake bigger (Myles 1995). Wealth here should be interpreted as broadly as possible and encompasses nonpriced benefits and costs such as the aesthetic appeal of landscapes.

When markets persistently, substantially, and systematically fail to allocate resources to their most highly valued use, then they are inefficient. The crucial term here is "persistently," because this signals the presence of a fundamental flaw in the operation of markets (Randall 1983). Typically, inefficiency in the form of the misallocation of natural resources arises when markets are incomplete because of the presence on nonexclusiveness (Randall 1983).

Changing the way the economy operates so as to improve economic efficiency, such as correcting a problem with the way the markets function, invariably means modifying how people behave. A wide variety of policy instruments may be used to change how people behave, but in simple terms, these instruments can be broadly summarized into regulations of varying complexity, incentives and charges of various kinds, market- based instruments, and various forms of education and persuasion(Vedung 1998, Connor et al. 2009, Bryan and Kandulu 2011, Velasquez and Hester 2013, Greenhalgh and Selman 2014, Mees et al. 2014).

The second basic reason that governments create policy is to change the distribution of wealth in the community. Again, wealth should be interpreted as broadly as possible. Changing the distribution of wealth in the community involves changing the way the economic cake is shared. Intervening to change the distribution of wealth in the community or between generations is justified on the basis of fairness or equity (Myles 1995). In principle, policy instruments such as income tax, unemployment benefits, and pensions are used to redistribute wealth in the community.

From a microeconomic perspective, the distinction between economic efficiency and equity is fundamental and crucial when it comes to policy (Howarth and Norgaard 1990, Myles 1995). An economy may be efficient but inequitable given the preferences of the community. In other words, the economy may be operating perfectly well in terms of generating wealth from scarce resources, but the community may well consider that wealth to be unfairly distributed among its members.

In these circumstances, the government, on behalf of the community, may seek to redistribute wealth more equitably and ideally should do so using a policy instrument that does not impair the efficiency of the economy (Little 1950, Henderson and Quandt 1980). This idea explains the preference among economists for the use of transfer payments, income taxes, pensions, and the like to resolve problems of equity or fairness. In principle then, equity problems may arise, and be resolved, independently of any concerns for the efficiency of the economy.

Conversely, an economy may be inefficient even though it is equitable. In other words, the economy may not be operating well in terms of generating wealth from scarce resources, but the community may well consider the wealth that is created to be fairly distributed among its members. The correction of inefficiencies in the economy necessarily involves changing the behavior of people. This is because, in terms of natural resources, inefficiency means that people are receiving incorrect signals about the use of the resource, resulting in the misallocation or misuse of the resource (Randall 1983). Consequently, changing these signals inevitably means changing the use of the resource and thereby changing behavior. This idea explains the reliance on policy instruments that change behavior, such as regulations, incentives, and charges, to correct efficiency problems with the economy in general and natural resources in particular.

Unfortunately, the correction of inefficiencies in the operation of the economy has consequences for the distribution of wealth in the community. Correcting a persistent inefficiency in the economy through a policy instrument to change peoples' behavior will create losses in wealth for some and corresponding gains in wealth for others. The broader community may view the resulting pattern of gains and losses as unfair. In these circumstances, the government, again on behalf of the community, may seek to redistribute wealth to counteract this unfairness. Again, this should be done using a policy instrument such as a transfer payment that does not impair the efficiency of the economy (Little 1950, Henderson and Quandt 1980). 
Accordingly, in seeking to redistribute the benefits and costs arising from changing peoples' behavior to correct an economic inefficiency, governments should avoid amending or modifying the policy instrument that was selected to create the change in behavior in the first place. To do otherwise would reintroduce the very inefficiency the policy was originally intended to correct. In short, different policy objectives (i.e., improved efficiency and equitable distribution of costs) should be addressed using different policy instruments (Tinbergen 1950, Eskeland and Jimenez 1991).

Therefore, from a microeconomic perspective, problems in natural resource management are economic efficiency problems, typically of the form of allocative inefficiency (Grafton et al. 2000). Inefficiencies of this nature are key characteristics of open access resources (Griffin and Bromley 1982, Stavins 2011) and attributable to the presence of externalities (Stavins 2011). Such externalities arise from the rival but nonexclusive nature of common-pool natural resources (Randall 1983). As noted above, the correction of these inefficiencies entails changing the behavior of the users of the resource in some manner.

Policy instruments that correct inefficiency by changing the behavior of resource users, such as a regulation or market-based instrument, invariably create costs for those who have to change. If the magnitude of these costs is regarded as unfair, then the appropriate policy response is to use another policy instrument, one that is efficiency neutral such as an income transfer, to redistribute the costs of change rather than modify or abandon the original behavior change instrument (the regulation or capand-trade scheme).

\section{EFFICIENCY AND EQUITY IN FORMULATING NATURAL RESOURCE POLICY}

We contend that careful discrimination between efficiency and equity when making three fundamental decisions during the policy formulation and decision-making stages (Jann and Wegrich 2006, Howlett 2012) of the policy cycle can provide greater clarity and focus for policy practitioners as they formulate policy. This will help practitioners navigate through some of the most criticized and contentious parts of the policy process. The three decisions are: (1) identifying a preferred mix of uses of the resource (or choosing the best mix of uses), (2) choosing a policy instrument to correct inefficiency and change resource use, and (3) choosing a mechanism to resolve any undesirable impacts of the chosen policy instrument on the distribution of wealth. The first decision is conceptually distinct from the second and third because it concerns expressing preferences about what the broader community views as a desirable portfolio of uses for the natural resource. Hence, the first decision is about formulating the policy objective, whereas the second and third decisions are about achieving that objective. In many instances, these three decisions may be considered iteratively as the policy problem and solutions are refined by policy practitioners.

\section{Choosing the best mix of uses for the resource}

The heart of many natural resource problems is that, in the absence of government intervention, as one person cannot prevent another person from using the resource, use of the resource is nonexclusive (Randall 1983). This means that a person can use the resource in ways that create losses for others without having to compensate others. As a result, natural resources can be persistently overcommitted to particular uses. Government intervention is required to correct this misallocation and change how a natural resource is used.

Resolving this first decision, then, involves finding a balance among the community and stakeholders in their preferences for resource use. To find this balance, criteria can be developed for deciding on the resource use mix, which may be expressed in ways such as beneficial cultural outcomes, resilient freshwater ecosystems, and economic sustainability (see Table 1 for an example of criteria used in a freshwater policy process in New Zealand).

Table 1. Illustrative criteria for choosing a preferred mix of uses.

Criteria $^{\dagger}$ — Does the mix of uses:

Provide for River Iwi to retain and use their taonga in accordance with their tikanga and kawa?

Give effect to River Iwi environmental, economic, cultural, and social relationships with land and water?

Enhance people's use of the river?

Achieve the range of values identified?

Take account of unique features and benefits?

Support resilient freshwater ecosystems?

Support interconnectedness and connectivity between land and water?

Support healthy populations of indigenous plants and animals?

${ }^{\dagger}$ Adapted from WRC (2016).

An aspect of this decision involves decisions about trade-offs between uses of the resource, not individual users of the resource. In deciding on a desirable mix of uses, the assessment of whether to intervene to change natural resource use depends on whether the benefits from intervening are judged to outweigh the costs. Tools such as scenario analysis (Wiek et al. 2011) and benefit cost analysis (Hanley and Spash 1993, Young and Loomis 2014) may be employed to identify feasible combinations of uses of a natural resource and the corresponding benefits and costs associated with each combination.

\section{Choosing an instrument to change resource use}

Having identified a desirable mix of uses, the second decision is choosing a policy instrument, or package of instruments, to achieve the change in resource use. This involves finding instruments that resolve the resource misallocation by changing who uses the resource and how the resource is used. The criteria governing the selection of such an instrument could include consistency with relevant legislation, technical feasibility, costeffectiveness, enforceability, and administrative efficiency.

Effective policy design and implementation is based on understanding why natural resource users do what they do (Rist 1998). Considerable effort may need to be directed at matching policy instruments to peoples' motivations and behavior if sound decisions about how to change the behavior of individual users are to be made. Hence, finding an effective and lowest cost combination of policy instruments requires knowing who uses the resource (e.g., farmers, foresters, energy generators, water suppliers, and others), how they use it (practices), and why they use it the way they do. This information provides insights to questions such as how many people can change, how they must change, how much it might cost them to change, and how quickly they can change. 
A key consideration is whether enough users will voluntarily change their behavior or whether users will need to be compelled to change. Another consideration is whether an individual's use of the resource can be measured or estimated. Some policy instruments such as incentives, charges, and cap-and-trade schemes are only feasible if there is an acceptable accurate and inexpensive way of measuring or estimating a person's use of the resource. Table 2 provides an illustrative example of criteria used to assist with the choice of policy instruments for a contemporary policy process for freshwater resources in New Zealand.

Table 2. Illustrative criteria for choosing an instrument to change resource use.

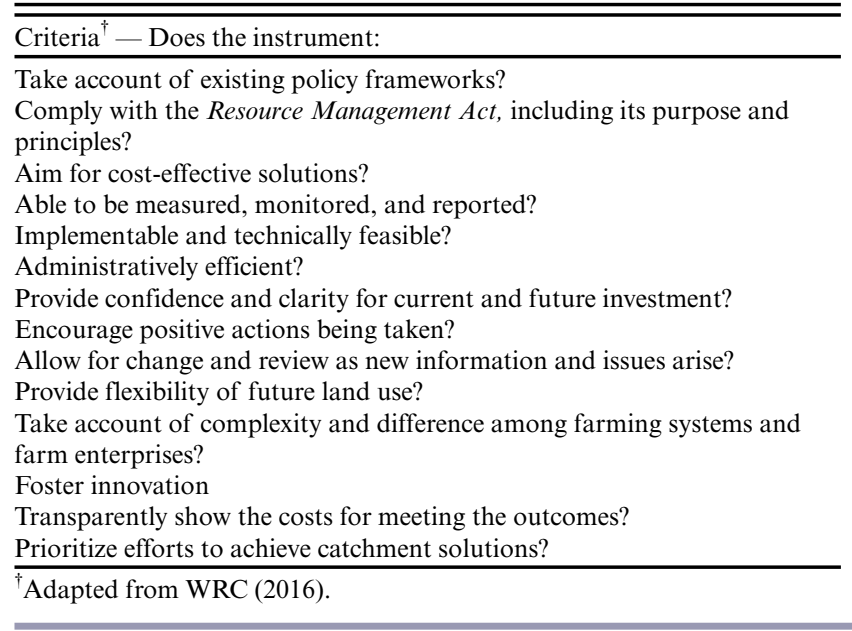

There is extensive literature on policy instrument choice, and there is a range of tools (e.g., Greenhalgh and Selman 2014, Mees et al. 2014) that may be used in making decisions about how to change the behavior of individual users. Importantly, efficiency is the focus of this choice.

\section{Sharing the costs of change}

Having identified the desirable mix of natural resource uses and chosen one or more instruments to achieve that mix, a third matter is deciding how the cost of changing to the desired mix is shared among resource users and the broader community. This decision involves deciding what form of compensation, if any, will be given to those users who will experience losses from changing their resource use, and who will pay that compensation. The process may also include an assessment of who was bearing the costs prior to the proposed policy intervention. Depending on circumstances, this decision may lead to modifications in the design of the chosen policy instrument or the development of complementary policy measures designed specifically to redistribute the costs of change.

The focus here is on equity or fairness in the distribution of costs, both in terms of existing costs to resource users and potential future costs of changing resource use. Fairness might be judged in a number of ways (see Table 3 for some examples). These judgements could include general principles such as "polluter pays" or "beneficiary pays," as well as more specific principles such as recognizing any beneficial efforts already made by individuals in how they use natural resources. Other considerations may also come into play such as minimizing social disruption or other social impacts (Challen 2000).
Table 3. Illustrative criteria for sharing the costs of change.

\begin{tabular}{l}
\hline \hline Criteria $^{\dagger}$ - Does the measure: \\
\hline Provide realistic time frames for change? \\
Achieve sound principles for allocation? \\
Recognize efforts already made? \\
Exhibit proportionality (i.e., those contributing to the problem contribute \\
to the solution)? \\
Result in outcomes people can identify with, own, and feel proud of? \\
Take an evidence-based and knowledge-based approach (including \\
Mātauranga Māori)? \\
Set transparent limits and definitions? \\
Minimize social disruption and provide social benefit? \\
\hline 'Adapted from WRC (2016).
\end{tabular}

Understanding and agreeing on community preferences for sharing the costs of changing resource use is usually challenging and contentious. An impasse at this point may mean that decisions made in regard to the best mix of uses for the resource need to be reconsidered. However, avoiding this impasse is a key reason for separating efficiency and equity decisions and clarifying the tradeoffs between the two.

\section{Lake Taupo: an idealized example}

We use the cap-and-trade scheme established for Lake Taupo (Kaine et al. 2008, Young and Kaine 2010, Duhon et al. 2015, Kerr at al. 2015, OECD 2015) to illustrate how the three decisions relate to real-world policy formulation and decision making. Lake Taupo is an iconic lake in New Zealand. Formed from an ancient volcano, the lake is famous for its beauty and for tourism. Water quality in Lake Taupo is excellent but was at risk of declining because of the sensitivity of the lake to increasing nitrogen emissions from surrounding farms and, to a lesser extent, human wastewater disposal.

The Waikato Regional Council is the regulatory authority in New Zealand tasked with managing natural resources such as freshwater in the Waikato Region, which includes Lake Taupo. The Council determined that, rather than have the lake continue to act as an assimilative body for agricultural nitrogen emissions, the preferred mix of uses from the community's perspective was recreational activities and tourism and the protection of environmental and cultural values (WRC 2007).

The initial policy instrument that was proposed to change resource use was the regulation of farming activities. Farmers opposed the restrictions on their activities and the costs entailed in those restrictions. Thus, following consultation with local indigenous people, landholders, and other stakeholders, a marketbased instrument, i.e., a cap-and-trade market for nitrogen emissions, was proposed instead as the preferred policy instrument (WRC 2007). From an efficiency perspective, a capand-trade market is preferable to the direct regulation of farming activities for three reason. Creation of the market: (1) dealt directly with the problem of nonexclusive access to the resource by restricting nitrogen emissions in aggregate; (2) improved technical efficiency, in principle, by providing farmers with autonomy in deciding how to meet their regulated nitrogen emission constraint; and (3) improved allocative efficiency by facilitating the transfer of nitrogen discharge permits between 
uses through trading. Trading also offered the potential to maximize the economic benefits created from the limited emissions that were allowed.

The effect on the distribution of future costs created by the proposed cap-and-trade scheme was resolved in two ways. First, nitrogen discharge permits were allocated to farmers using estimated historical emissions. This decision was based on the fact that the Council believed that farmers had developed their land in good faith in the absence of regulation and therefore should not to be excessively penalized. The Council also believed that the difference in historical emissions between farms was not related to their motivation to protect the environment.

Another option considered was to allocate the nitrogen discharge permits based on averaging emissions across either individual sectors (e.g., pastoral farming, forestry, etc.) or the watershed. The Council, however, believed averaging emissions would unfairly advantage farmers with below-average emissions and unfairly disadvantage farmers with above-average emissions. By using historical emissions, however, farmers would still bear all future costs of using their land within their permitted discharge levels.

Second, the costs of the aggregate reduction in nitrogen emissions to the lake were to be shared among taxpayers and ratepayers. A public fund, to be administered by a Trust established by the government (Lake Taupo Protection Trust 2008), was established to buy and retire permits (or land) until the volume of allocated emission permits was reduced by an agreed amount. The purchase of permits by the Trust was a mechanism for ameliorating the undesirable redistributive effects of changing resource use by transferring some tax and rate revenue to farmers and other landowners. Hence, equity in the distribution of the costs of reducing nitrogen emissions to the cap was resolved through the creation of the Trust and the purchase of land and discharge permits using funds raised from taxpayers and ratepayers.

As of 2015, all farmers were in compliance with the new rules, and permanent and temporary trades of nitrogen discharge permits had occurred (Kerr et al. 2015).

\section{DISCUSSION}

Clearly distinguishing between efficiency and equity, and the kinds of policy instrument appropriate to each, provides a number of helpful insights for designing natural resource policy. The first insight is when and how equity (as judged by fairness) can be addressed during policy formulation. Changing the way a resource is used inevitably means some members of the community will experience losses while others will gain. The distribution of these costs, in particular, their magnitude for particular industries, sectors, or individuals, should not be an important influence on judging whether or not changing the resource use is worthwhile. Rather, the merit of changing the resource use should be judged on the difference between the benefits in aggregate and the costs in aggregate. Therefore, equity in regard to the cost of changing resource use is not part of the decision on the preferred mix of uses.

Equity also does not influence the choice of policy instrument to change behavior. Instead, criteria related to the feasibility, effectiveness, and efficiency of instruments in achieving behavior change should govern these choices. Instrument choice relates more to the nonexcludable nature of the resource that results in its persistent misallocation or resource characteristics such as measurability.

Although there are political dimensions to instrument choice, in particular, whether behavior change should be voluntary or made compulsory, the choice is best driven by the effectiveness of the instrument in achieving the requisite scale of behavior change, not equity, given that the decision has already been reached that the aggregate benefits of changing the resource use exceed the costs.

The specifics of instrument implementation (such as eligibility criteria for incentives, exclusions from regulations, and the method employed to allocate rights under a cap-and-trade scheme) will affect the distribution of the costs of change among resource users. Where efficiency in instrument implementation and equity in bearing costs coincide, the possibility arises that equity in the distribution of costs could also be addressed to a limited extent in the implementation of the instrument chosen to change behavior. For example, small-scale users of a resource may be exceptions to a regulation because it is considered unfair, as well as impractical, to regulate them.

Relatedly, the method of allocating rights under a cap-and-trade scheme will affect the distribution of the cost of changing resource use among individual users, though not the overall cost itself. Hence, while efficiency considerations govern the choice of the instrument employed to change resource use, equity considerations as well as practical matters could influence the way in which the chosen instrument is designed and implemented.

The second implication, following from the preceding discussion, concerns the types of criteria employed in the literature to assess and select policy instruments. Much of the literature on policy instruments that are intended to change behavior proposes that instrument choice be evaluated using equity criteria, as well as efficiency and other criteria (see for example U.S. Congress Office of Technology Assessment 1995, Young et al. 1996, Goulder and Parry 2008, Mees et al. 2014). However, this outlook tends to confound the decision about which policy instruments to use because it is unlikely that the most efficient policy instrument will be the most equitable in terms of the distribution of costs. Instead, equity should drive the need for complementary mechanisms such as transfer payments to distribute the costs of change more fairly. To include equity as a criterion in instrument choice in this context conflates the choice of an instrument to change behavior and resource use with choosing a means to redistribute consequent gains and losses. This reasoning supports our premise that instrument choice to reallocate resource use and mechanisms to redistribute any corresponding costs are related but separate policy objectives and should be addressed using separate instruments.

Introducing equity and fairness too early in policy processes is likely to result in contentious processes and greater conflict between and among stakeholders and those formulating policy. Therefore, this raises interesting questions as to the proper role of consultation with and participation of stakeholders in the policy process, especially because collaborative and participatory approaches to policy development are growing in popularity (Yaffee and Wondolleck 2003, Webler and Tuler 2006, Barnaud 
and Van Passen 2013). The arguments we have advanced here suggest that the views of individuals who anticipate experiencing losses (or gains) may, and perhaps should, be relevant to decisions about sharing costs and benefits of changing resource use. The views of those individuals, or more accurately, the information they can provide, on the nature and scale of costs and benefits will be relevant to considerations of the aggregate net benefits of changing resource use where the overall merit for the community of changing resource use is considered. However, when it comes to choosing a policy instrument to change resource use, those views have limited relevance. Although they may provide useful information about the relative efficiency and effectiveness of different policy instruments, the choice between those instruments is a decision that should not be theirs to make.

These arguments suggest that the real benefits of participatory or collaborative approaches (New Zealand Planning Institute, collaborative planning: https://www.planning.org.nz/Category? Action=View\&Category $\mathrm{id=1229}$ ) are for making decisions on how to share the costs of changing resource use. A more consultative approach with stakeholders may be more appropriate for choosing the preferred mix of uses and the most efficient policy instrument to achieve that resource mix.

\section{CONCLUSION}

Deliberating on policy design to manage natural resources with clarity and precision is a difficult task, even for professional and highly experienced policy practitioners. Many of the challenges encountered by policy practitioners, arguably, arise from confounding the problem of crafting policy instruments to change how resources are used (a behavioral matter related to resource management) with the consequential problem of who bears the cost of changing how resources are used (an equity matter).

Drawing on the microeconomic theory of market failure, we outlined why the problem of changing how a natural resource is used is fundamentally distinct from the problem of fairly distributing the cost arising from changing how the resource is used. The former is a misallocation problem that requires intervening to change the behavior of resource users. The latter is an equity problem that requires intervening to redistribute the costs of change while attempting to avoid undermining the solution to the misallocation problem. Thus, instrument choice to reallocate resource use and mechanisms to redistribute any corresponding costs address related but separate policy objectives. Consequently, separate instruments should be used to address these different objectives.

By considering efficiency and equity as two different policy objectives, it may be possible to reduce the conflation of these criteria during the formulation of policy and, in so doing, assist the deliberations of policy makers as they decide how to manage natural resources.

Responses to this article can be read online at: http://www.ecologyandsociety.org/issues/responses. $\mathrm{php} / 9133$

\section{Acknowledgments:}

We acknowledge the Ministry of Business Innovation and Employment's Science and Innovation Group, whose funding of the Freshwater Values, Monitoring and Outcomes Programme (C09X1003) supported this research. We thank several anonymous reviewers for their invaluable comments and criticisms.

\section{LITERATURE CITED}

Barnaud, C., and A. Van Paassen. 2013. Equity, power games, and legitimacy: dilemmas of participatory natural resource management. Ecology and Society 18(2):21. http://dx.doi. org/10.5751/es-05459-180221

Bromell, D. 2012. Evidence, values and public policy. ANZSOG Occasional Paper. Australia New Zealand School of Government, Melbourne, Australia. [online] URL: https://www. anzsog.edu.au/resource-library/research/evidence-values-and-publicpolicy

Bryan, B. A., and J. M. Kandulu. 2011. Designing a policy mix and sequence for mitigating agricultural non-point source pollution in a water supply catchment. Water Resources Management 25(3):875-892. http://dx.doi.org/10.1007/s11269-010-9731-8

Challen, R. 2000. Institutions, transaction costs and environmental policy: institutional reform for water resources. Edward Elgar, Cheltenham, UK.

Cilliers, P., H. C. Biggs, S. Blignaut, A. G. Choles, J. S. Hofmeyr, G. P. W. Jewitt, and D. J. Roux. 2013. Complexity, modeling, and natural resource management. Ecology and Society 18(3):1. http:// dx.doi.org/10.5751/es-05382-180301

Connor, J., D. D. Hatton MacDonald, M. Morrison, and A. Cast. 2009. Evaluating market instruments for managing diffuse source pollution in Lake Taupo, New Zealand. Environmentalist 29 (4):348-359. http://dx.doi.org/10.1007/s10669-008-9197-x

Cox, M., G. Arnold, and S. Villamayor Tomás. 2010. A review of design principles for community-based natural resource management. Ecology and Society 15(4):38. http://dx.doi. org/10.5751/es-03704-150438

Daigneault, A., S. Greenhalgh, and O. Samarasinghe. 2017. Equitably slicing the pie: water policy and allocation. Ecological Economics 131:449-459. http://dx.doi.org/10.1016/j.ecolecon.2016.09.020

de Serres, A., F. Murtin, and G. Nicoletti. 2010. A framework for assessing green growth policies. OECD Economics Department Working Paper 774. OECD Publishing, Paris, France. http://dx. doi.org/10.1787/5kmfj2xvcmkf-en

Duhon, M., H. McDonald, and S. Kerr. 2015. Nitrogen trading in Lake Taupo: an analysis and evaluation of an innovative water management policy. Motu Working Paper 14-14. Motu Economic and Public Policy Research, Wellington, New Zealand. http://dx. doi.org/10.2139/ssrn.2653472

Dwyer, G., R. Douglas, D. Peterson, J. Chong, and K. Maddern. 2006. Irrigation externalities: pricing and charges. Productivity Commission Staff Working Paper. Australian Government Publishing Service, Melbourne, Australia. [online] URL: $\underline{\text { http:// }}$ www.pc.gov.au/research/supporting/irrigation-externalities 
Eskeland, G. S., and E. Jimenez. 1991. Choosing policy instruments for pollution control: a review. Policy, Research, and External Affairs Working Paper WPS624. World Bank, Washington, D.C., USA. [online] URL: http://documents.worldbank.org/curated/ en/251021468739136743/Choosing-policy-instruments-for-pollutioncontrol-a-review

Godwin, A. 2016. Proposed 'pollution diet' spurs controversy. Water World Magazine. [online] URL: http://www.waterworld. com/articles/uwm/articles/print/volume-4/issue-4/viewpoint/proposedpollution-diet-spurs-controversy.html

Goulder, L. H., and I. W. H. Parry. 2008. Instrument choice in environmental policy. Resources for the Future Discussion Paper 08-07. Resources for the Future, Washington, D.C., USA. [online] URL: http://www.rff.org/files/sharepoint/WorkImages/Download/ RFF-DP-08-07.pdf

Grafton, R. Q., D. Squires, and K. J. Fox. 2000. Private property and economic efficiency: a study of a common-pool resource. Journal of Law and Economics 43(2):679-714. http://dx.doi. org/10.1086/467469

Greenhalgh, S., and M. Selman. 2014. Review of policy instruments for ecosystem services. Landcare Research Science Series 42. Manaaki Whenua Press, Lincoln, New Zealand. [online] URL: http://www.mwpress.co.nz/science-series/policy-instrumentsfor-ecosystem-services

Griffin, R. C., and D. W. Bromley. 1982. Agricultural runoff as a nonpoint externality: a theoretical development. American Journal of Agricultural Economics 64(3):547-552. http://dx.doi. org/10.2307/1240648

Grimble, R., and K. Wellard. 1997. Stakeholder methodologies in natural resource management: a review of principles, contexts, experiences and opportunities. Agricultural Systems 55 (2):173-193. http://dx.doi.org/10.1016/s0308-521x(97)00006-1

Hanley, N., and C. L. Spash. 1993. Cost-benefit analysis and the environment. Edward Elgar, Aldershot, UK.

Hatton MacDonald, D., J. Connor, and M. Morrison. 2004. Economic instruments for managing water quality in New Zealand. Final report for New Zealand Ministry for the Environment. CSIRO Land and Water, Canberra, Australia. [online] URL: http://www.mfe.govt.nz/publications/fresh-water/economic-instrumentsmanaging-water-quality-new-zealand

Henderson, J. M., and R. E. Quandt. 1980. Microeconomic theory: a mathematical approach. McGraw-Hill, New York, New York, USA.

Heracleous, L. T. 1994. Rational decision making: myth or reality? Management Development Review 7(4):16-23. http://dx.doi. org/10.1108/09622519410771628

Howard, C. 2005. The policy cycle: a model of post-Machiavellian policy making? Australian Journal of Public Administration 64 (3):3-13. http://dx.doi.org/10.1111/j.1467-8500.2005.00447.x

Howarth, R. B., and R. B. Norgaard. 1990. Intergenerational resource rights, efficiency, and social optimality. Land Economics 66(1):1-11. http://dx.doi.org/10.2307/3146678

Howlett, M. 2012. The lessons of failure: learning and blame avoidance in public policy-making. International Political Science
Review 33(5):539-555. http://dx.doi.org/10.1177/0192512112453603

Hukkinen, J., E. Roe, and G. I. Rochlin. 1990. A salt on the land: a narrative analysis of the controversy over irrigation-related salinity and toxicity in California's San Joaquin Valley. Policy Sciences 23(4):307-329. http://dx.doi.org/10.1007/bf00141324

Jann, W., and K. Wegrich. 2006. Theories of the policy cycle. Pages 43-62 in F. Fischer, G. J. Miller, and M. S. Sidney, editors. Handbook of public policy analysis: theory, politics, and methods. CRC Press, Boca Raton, Florida, USA.

Kaine, G., M. Higson, and J. Young. 2008. A tradable emissions permit program for nitrogen in Lake Taupo. Pages 893-898 in The Organizing Committee, editor. Multifunctional grasslands in a changing world: proceedings of the XXI International Grasslands Congress and the VIII International Rangeland Congress. Volume II. China Press, Hohhot, China.

Kerr, S., S. Greenhalgh, and G. Simmons. 2015. The Taupo nitrogen market: the world's only diffuse source trading programme. Motu Note 20. Motu Economic and Public Policy Research Trust, Wellington, New Zealand. [online] URL: http://motu.nz/ourwork/environment-and-resources/nutrient-trading-and-water-quality/ the-taupo-nitrogen-market-the-worlds-only-diffuse-source-tradingprogrammel

Lake Taupo Protection Trust. 2008. Strategic plan 2008-2011. Lake Taupo Protection Trust, Hamilton East, New Zealand. [online] URL: http://www.laketaupoprotectiontrust.org.nz/file/ downloads/pdf/stratplan.pdf

Little, I. M. D. 1950. A critique of welfare economics. Clarendon Press, Oxford, UK.

Mees, H. L. P., J. Dijk, D. van Soest, P. P. J. Driessen, M. H. F. M. W. van Rijswick, and H. Runhaar. 2014. A method for the deliberate and deliberative selection of policy instrument mixes for climate change adaptation. Ecology and Society 19(2):58. http://dx.doi.org/10.5751/ES-06639-190258

Muradian, R., and L. Rival. 2012. Between markets and hierarchies: the challenge of governing ecosystem services. Ecosystem Services 1(1):93-100. http://dx.doi.org/10.1016/j. ecoser.2012.07.009

Myles, G. D. 1995. Public economics. Cambridge University Press, Cambridge, UK. http://dx.doi.org/10.1017/cbo9781139170949

Nutt, P. C. 2008. Investigating the success of decision making processes. Journal of Management Studies 45(2):425-455. http:// dx.doi.org/10.1111/j.1467-6486.2007.00756.x

Organisation for Economic Co-operation and Development (OECD). 2015. The Lake Taupo nitrogen market in New Zealand: a review for policy makers. OECD Environment Policy Paper 04. OECD, Paris, France. http://dx.doi.org/10.1787/5jrtg113p9mr-en

Ostrom, E. 1990. Governing the commons: the evolution of institutions for collective action. Cambridge University Press, Cambridge, UK.

Pascual, U., R. Muradian, L. C. Rodríguez, and A. Duraiappah. 2010. Exploring the links between equity and efficiency in payments for environmental services: a conceptual approach. Ecological Economics 69(6):1237-1244. http://dx.doi.org/10.1016/ j.ecolecon.2009.11.004 
Phillips, S. 2012. Murray-Darling Plan reflects the failure of the government. ABC Environment May 31, 2012. [online] URL: http://www.abc.net.au/environment/articles/2012/05/31/3514567. $\underline{h t m}$

Randall, A. 1983. The problem of market failure. Natural Resources Journal 23(1):131-148. [online] URL: http://lawschool. unm.edu/nrj/volumes/23/1/08 randall problem.pdf

Rist, R. C. 1998 Choosing the right policy instrument at the right time: the contextual challenges of selection and implementation. Pages 149-163 in M.-L. Bemelmans-Videc, R. C. Rist, and E. Vedung, editors. Carrots, sticks and sermons: policy instruments and their evaluation. Transaction Publishers, New Brunswick, New Jersey, USA.

Rose, A., and B. Stevens. 1993. The efficiency and equity of marketable permits for $\mathrm{CO}_{2}$ emissions. Resource and Energy Economics 15(1):117-146. http://dx.doi.org/10.1016/0928-7655 (93)90021-L

Sabatier, P. A., editor. 2007. Theories of the policy process. Westview Press, Boulder, Colorado, USA.

Sidder, A. 2016. Understanding the controversy behind the Dakota Access Pipeline. Smithsonian Magazine September 14, 2016. [online] URL: http://www.smithsonianmag.com/smartnews/understanding-controversy-behind-dakota-accesspipeline-180960450/?no-ist

Smith, C. A., and C. A. Sime. 2007. Policy issues related to wolves in the northern Rocky Mountains. Pages 391-402 in Transactions of the 72nd North American Wildlife and Natural Resources Conference. Wildlife Management Institute, Washington, D.C., USA.

Stavins, R. N. 2011. The problem of the commons: still unsettled after 100 years. American Economic Review 101(1):81-108. [online] URL: http://www.jstor.org/stable/41038783

Tadaki, M., and J. Sinner. 2013. Structuring freshwater values: meaning and conflict in a regional plan. Report 2282. Cawthron Institute, Nelson, New Zealand.

Tinbergen, I. 1950. On the theory of economic policy. NorthHolland Publishing, Amsterdam, The Netherlands. [online] URL: hdl.handle.net/1765/15884

U.S. Congress Office of Technology Assessment. 1995. Environmental policy tools: a user's guide. OTA-ENV-634. U.S. Government Printing Office, Washington, D.C., USA.

Vedung, E. 1998. Policy instruments: typologies and theories. Pages 21-58 in M.-L. Bemelmans-Videc, R. C. Rist, and E. Vedung, editors. Carrots, sticks and sermons. Transaction Publishers, New Brunswick, New Jersey, USA.

Velasquez, M., and P. T. Hester. 2013. An analysis of multi-criteria decision making methods. International Journal of Operations Research 10(2):56-66. [online] URL: http://www.orstw.org.tw/ ijor/vol10no2/ijor vol10 no2 p56 p66.pdf

Waikato Regional Council (WRC). 2007. Proposed Waikato Regional Plan variation 5 - Lake Taupo catchment (Hearings Committee recommendations version). Environment Waikato Policy Series 2007/09. Waikato Regional Council, Hamilton, New
Zealand. [online] URL: https://www.waikatoregion.govt.nz/ assets/PageFiles/7058/Explanation $\% 20$ and $\% 20$ evaluation $\% 20$ of $\%$ 20alternatives, $\% 20$ benefits $\% 20$ and $\% 20$ costs.pdf

Waikato Regional Council (WRC). 2016. The collaborative stakeholder group's policy selection criteria. Waikato Regional Council, Hamilton, New Zealand. [online] URL: https://www. waikatoregion.govt.nz/assets/PageFiles/36829/Collaborative $\%$ 20Stakeholder $\% 20$ Group $\% 20$ policy $\% 20$ selection $\% 20$ criteria.pdf

Webler, T., and S. Tuler. 2006. Four perspectives on public participation process in environmental assessment and decision making: combined results from 10 case studies. Policy Studies 34 (4):699-722. http://dx.doi.org/10.1111/j.1541-0072.2006.00198.x

Wiek, A., L. Withycombe, and C. L. Redman. 2011. Key competencies in sustainability: a reference framework for academic program development. Sustainability Science 6 (2):203-218. http://dx.doi.org/10.1007/s11625-011-0132-6

Yaffee, S. L., and J. M. Wondolleck. 2003. Collaborative ecosystem planning processes in the United States: evolution and challenges. Environments 31(2):59-72.

Young, J., and G. Kaine. 2010. Application of the Policy Choice Framework to Lake Taupo catchment. Environment Waikato Technical Report 2010/20. Environment Waikato, Hamilton, New Zealand. [online] URL: https://www.waikatoregion.govt.nz/ services/publications/technical-reports/tr/tr201020

Young, M. D., N. Gunningham, J. Elix, J. Lambert, B. Howard, P. Grabosky, and E. McCrone. 1996. Reimbursing the future: an evaluation of motivational, voluntary, price-based, property-right and regulatory incentives for the conservation of biodiversity. Biodiversity Series Paper 9. CSIRO Division of Wildlife and Ecology, Australian Centre for Environmental Law, and Community Solutions, Canberra, Australia.

Young, R. A., and J. B. Loomis. 2014. Determining the economic value of water: concepts and methods. Taylor and Francis, Oxford, UK. 